\title{
Digestion in the Plaice (Pleuronectes platessa).
}

\author{
By \\ L. E. Bayliss, Ph.D., \\ Physiologist at the Plymouth Laboratory.
}

With 6 Figures in the Text.

THE study of the digestive processes in the teleost fishes presents some interest since, although the structure of the alimentary canal is in general very similar to that of the mammalia, there may be certain important differences. For example, in many fishes there is no anatomical stomach (Fundulus, Babkin and Bowie, 1928), while in others there is a stomach, but no acid is secreted (Zoarces, Mackay, 1929a). Again, in most teleost fishes, the pancreatic tissue is scattered diffusely throughout the abdominal cavity, and it is problematical whether there is any external secretion of digestive juices, and, if there is, how the juices reach the alimentary canal. Finally, many fishes possess peculiar diverticula of the duodenum at the pylorus (the pyloric cæca), the function of which is not exactly known.

\section{Methods.}

It is impracticable, from an animal the size of the average plaice, to obtain sufficient quantities of pure digestive juices to enable one to make an adequate study of their enzyme contents. It has been necessary, therefore, to make extracts of the mucous membranes of the various parts of the digestive tract-usually with glycerol, but in some cases with $30 \%$ alcohol, and, in the case of the stomach, with N/10 hydrochloric acid-and to study the enzyme content of the extracts.

In most cases, the fish was stunned by a blow on the head, and killed by pithing, although in a few cases, the fish was anæsthetised with urethane. The whole alimentary canal was then removed, by carefully dissecting away the attachments to the mesentery, and separated into the various components; these were slit longitudinally, washed under the tap and the mucous membrane scraped off on a glass plate. The scrapings were then ground with sand, and extracted for about two days with rather more than an equal volume of glycerol or other extraction fluid (compare Mackay, 1929a). The extracts were then diluted with $\mathrm{N} / 20 \mathrm{HCl}$ (stomach) or $\mathrm{N} / 20 \mathrm{NaOH}$ (intestine), strained through muslin and made up to the volume required for the tests. This was usually about $1 \mathrm{ml}$. per $100 \mathrm{~g}$. 
fish, but the actual dilution varied on different occasions. The addition of acid or alkali facilitated the filtration, and brought the extract to approximately the appropriate acidity for the tests; it also prevented the proteins from coagulating when the extracts were boiled to destroy the enzymes. The protein concentration of the extracts varied, but lay between $0 \cdot 1 \%$ and $0.5 \%$.

The solutions were buffered during digestion, each tube containing $1 \mathrm{ml}$. of the extract, $1 \mathrm{ml}$. of $\mathrm{M} / 5$ buffer, and $1 \mathrm{ml}$. of the substrate solution. Since the extracts were themselves somewhat buffered, the final value of the acidity was different from that of the original buffer solution; it was measured when necessary, with the quinhydrone electrode.

Digestion was carried out in a water bath at $25 \cdot 5^{\circ} \pm 0 \cdot 15^{\circ}$. Hitherto, most studies of enzymes from cold-blooded animals have been carried out either at $37^{\circ}$ or at room temperature. It was felt that a temperature as high as $37^{\circ}$ might introduce abnormal effects, while the reactions would proceed so slowly at room temperature that significant effects might be missed : a compromise was therefore preferred. There would appear, however, to be no evidence that the enzymes behave in any way differently at $37^{\circ}$, room temperature, or $25^{\circ}$.

When comparing the enzymic activities of different organs, it was felt that it was more satisfactory to compare, for example, the lipoclastic activity of all the liver from a kilogram of fish, with that of all the intestinal mucous membrane, rather than to compare the activity of a gram of liver with a gram of intestinal mucous membrane.

\section{The Digestion of Proteins.}

Methods. Northrop (1932) recommends the following methods for the study of peptic activity: (1) the change in viscosity, (2) the decrease in protein nitrogen, and (3) the decrease in peptide linkages (formol titration); gelatin, casein and edestin may be used as substrates. At the beginning of this work the method involving carmine fibrin as substrate was used; later this was replaced by a modification of Northrop's method (2) and by the formol titration method (3); method (1) was not used.

While the carmine fibrin method is satisfactory so long as the range of hydrogen-ion concentration is restricted to $\mathrm{pH}$ less than 4 or so, it is useless in alkaline solutions (for testing for trypsin for example), since the carmine is dissolved off the fibrin even in the absence of any proteoclastic action. Vonk (1927) recommends the use of fibrin stained with Spirit Blue (diphenyl-rosaniline) for investigating tryptic activity, and, after studying the properties of a number of similar dyes available in the laboratory, gentian violet was found satisfactory. This was only used for a few experi- 
ments, however, since it was found that bile dissolved it off the fibrin more rapidly after boiling than before, and, on one occasion, intestinal extract behaved similarly. It was found also, that the amount dissolved off by the boiled extract depended upon the acidity both with gentian violet and carmine, so that a separate control was necessary for every value of acidity studied.

When this method had been rejected, Northrop's method (2) was adopted, using $2 \%$ casein or normal horse serum diluted to one-fifth, as substrates. The coagulable protein was estimated initially, and after a suitable period, in the digests and in controls containing boiled extract, by the method of Kerridge (1931). This consists in adding a known proportion of a suspension of India ink and then precipitating both protein and ink with trichloracetic acid. The greyness of the resulting suspension is then compared, by reflected light, with that of standard protein solutions similarly precipitated.

Polypeptidases, and in some cases proteinases, were estimated by formol titration, peptone being used as substrate for the former. One drop of $0 \cdot 1 \%$ phenol phthalein solution was added to each ml. of the digest, and the whole, or an aliquot part, titrated to a definite pink colour with $\mathrm{N} / 50 \mathrm{NaOH}$ containing one drop of the phenol phthalein solution per ml. $0.1 \mathrm{ml}$. of $40 \%$ formol (neutralised to phenol phthalein) was then added to each $\mathrm{ml}$. and the solution titrated to the same colour as before. To facilitate this, the digests were titrated in pairs (usually " active" and "boiled control") both being brought to the same pink colour ; formol was then added to the first, which was titrated to the colour of the second, whereupon formol was added to the second, and this titrated to the colour of the first.

This proved to be the only satisfactory method of investigating the proteoclastic activity of the bile, since its colour precluded the use of the Kerridge method; moreover, its surface activity resulted in a different degree of granularity of the precipitate on different occasions, which made the comparison even more difficult.

\section{RESULTS.}

\section{A. The Stomach.}

That extracts of the mucous membrane of the stomach digest protein in acid solution has been shown by all three methods. The optimum $\mathrm{pH}$ appears to lie between 1.5 and 2.5 , and no digestion takes place in solutions alkaline to $\mathrm{pH} 5 \cdot 5$. Proteins do not appear to be broken down beyond the polypeptide stage, since the extracts have no action on peptone (formol titration method, Table I). No difference could be detected between the $\mathrm{pH}$ optima of the glycerol extracts and of the acid extracts, but it must 
be admitted that, possibly owing to the technique employed, there appeared to be no clear-cut and regular influence of the hydrogen-ion concentration in either case between $\mathrm{pH} 1.5$ and $\mathrm{pH} 3$ (Fig. 1). The absence of any activity at acidities less than $\mathrm{pH} 5 \cdot 5$, and the similarity between the behaviour of the acid and glycerol extracts, indicate the absence of considerable quantities of cathepsin. These extracts appear to differ in this respect from those of mammalian gastric mucous membrane studied by Willstätter and Bamann (1928), which regularly contained both cathepsin and erepsin, greater quantities being present in glycerol extracts than in acid extracts.

The stomachs of fishes $78,81,90$ and 93 , to which pilocarpine had been administered for some hours (see later), were found to have secreted

\section{TABLE I.}

\section{Proteoclastic Action of Extracts of Mucosa of Stomach and Intestine, and of Bile obtained by Slitting Gall-Bladder.}

Difference between the formol titration figures (ml. $\mathrm{N} / 50 \mathrm{NaOH}$ ) of solutions containing $1 \mathrm{ml}$. buffer ( $\mathrm{pH} 2$ for stomach and $\mathrm{pH} 8$ for intestine and bile), $1 \mathrm{ml}$. substrate and $1 \mathrm{ml}$. extract, and similar solutions containing boiled extract, after 23 hours at $25^{\circ}$.

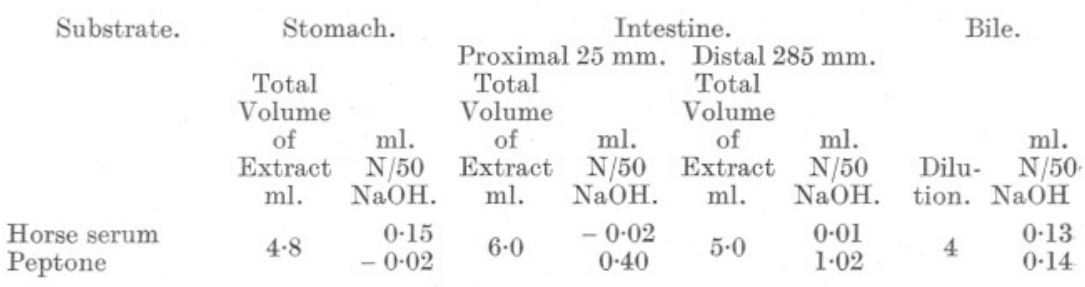

appreciable quantities of a clear viscid fluid. From the stomachs of Nos. 81,90 and 93 were obtained sufficient quantities of this fluid to enable it to be tested for proteoclastic activity. In all cases it was found that casein was digested at $\mathrm{pH} 2$, but not at any $\mathrm{pH}$ greater than $5 \cdot 5$. A slight action was observed with the extract from No. 93 at $\mathrm{pH} 5 \cdot 25$ and a definite action with that from No. 90 at $\mathrm{pH} 5 \cdot 0$. All these specimens of gastric juice were acid ( $\mathrm{pH} 5 \cdot 60,3 \cdot 85$ and $6 \cdot 45$ ), and those from fishes Nos. 90 and 93 contained $0.445 \mathrm{M}$. and $0.27 \mathrm{M}$. chlorides (equivalent to $2.6 \%$ and $1.6 \% \mathrm{NaCl}$ respectively). It is probable, therefore, that appreciable quantities of sea-water had leaked in through the cardiac sphincter. There is no doubt, therefore, that pepsin can be secreted into the lumen of the stomach.

\section{B. The Intestine.}

The plaice has no anatomically distinct pancreas, but according to Cole and Johnstone (1901), pancreatic tissue is distributed along the walls 
of the blood vessels of the mesentery, around the paired pyloric cæca (from which small ducts enter the intestine) and embedded in the liver, surrounding the smaller branches of the portal vein. It is thus impossible to remove the mucous membrane from the inside of the cæca (and the

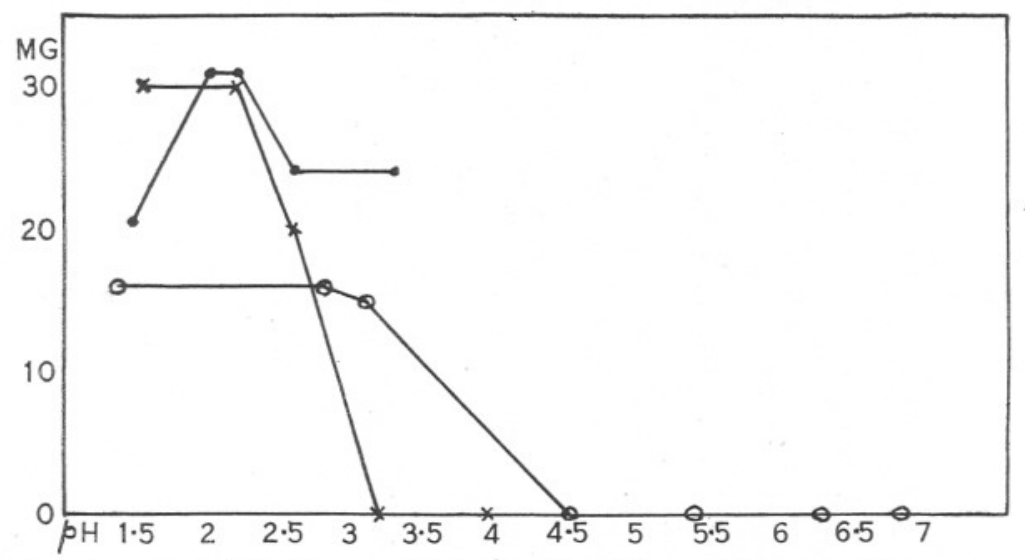

Frg. 1.-pH-Activity Curve of Proteinase from Mucous Membrane of Stomach.

Ordinates : mg. protein digested per hour by extract of whole mucous membrane of stomach from $1 \mathrm{~kg}$. of fish.

- Expt. 73/74. Acid extract. Substrate: casein. Duration of digestion : $1 \cdot 2$ hours.

$\times$ Expt. 32/34. Glycerol extract. Substrate: horse serum. Duration of digestion: $3 \cdot 3$ hours.

๑ Expt. 35/36. Glycerol extract. Substrate: horse serum. Duration of digestion: 11 hours.

neighbouring parts of the duodenum) without contamination with pancreatic tissue from the outside, the cæca being too small to be cleanly dissected away.

In many fish, the most distal of the four cæca could not be identified. Measurements made on those in which it was prominent, showed, however, that it could be presumed to lie within the proximal $10 \%$ to $15 \%$ of the intestine.

By analogy with the mammalia, then, one might expect that the mucous membrane obtained from the region of the intestine near the cæca would contain a trypsin-like enzyme, while the more distal portions would contain only an erepsin-like enzyme.

In experiments made in June and July, this was indeed found to be the case. Thus in Expt. 28, the extracts from the mucosa of the upper $3 \mathrm{~cm}$. of the intestine, and those from that of the remaining $18 \mathrm{~cm}$., were each made up to $6 \mathrm{ml}$. $1 \mathrm{ml}$. of the former digested $21 \mathrm{mg}$. of casein in 24 hours, while $1 \mathrm{ml}$. of the latter had no detectable action whatever at any acidity between $\mathrm{pH} 6 \cdot 8$ and $\mathrm{pH} 8 \cdot 7$. Later, however, in August and 
September, these results could not be confirmed, there being no detectable quantities of trypsin in either portion. In October, trypsin was found in small quantities in the distal regions, but none in the proximal. No explanation for this discrepancy can be advanced. In the early experiments, the analyses were made by the Kerridge method, using casein as substrate; in the later ones, both this method and the formol titration method were used, and normal horse serum was used as substrate in addition.

The optimum $\mathrm{pH}$ of this enzyme lies between $7 \cdot 5$ and $8 \cdot 5$, as will be seen from Figures 3 and 4 . There would appear to be cathepsin present

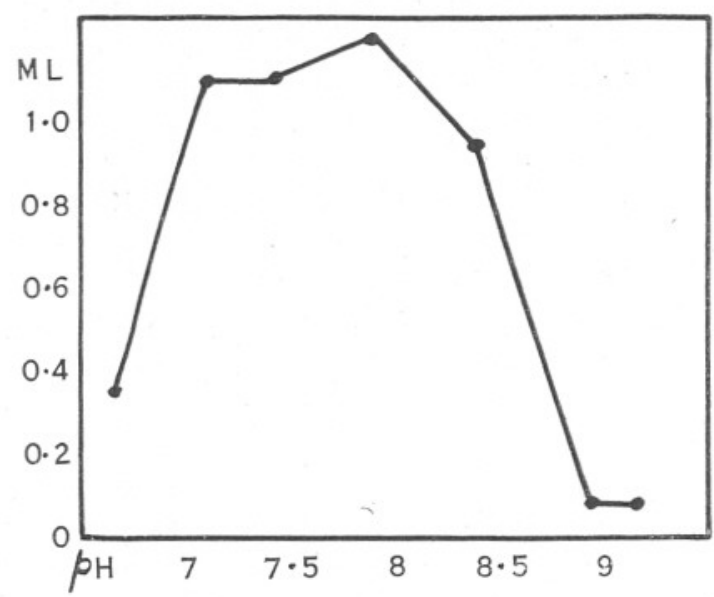

FIG. 2.- pH Activity Curve of Polypeptidase from Mucous Membrane of Intestine.

Ordinates : Decrease in peptide linkages (formol titration) produced per hour by whole extract of mucous membrane of $1 \mathrm{~kg}$. of fish.

Substrate : casein. Duration of digestion : 16 hours.

in some of the extracts, in addition to the trypsin, but the amount, in relation to that of the trypsin, is very variable.

An erepsin-like enzyme is present in relatively large quantities in the mucous membrane of all parts of the intestine, whose optimim $\mathrm{pH}$ lies between $7 \cdot 5$ and $8 \cdot 0$ (Fig. 2).

\section{Bile.}

Babkin and Bowie (1928) found that the bile of Fundulus heteroclitus, as obtained from the gall-bladder, contained a protease, a lipase and an amylase. Mackay (1929b), however, found that the bile of this fish was free from enzymes if, before puncturing the gall-bladder, the pancreatic tissue surrounding it was destroyed by immersion in Bouin's fluid for one minute. 
In the plaice, also, the bile has been found to contain a protease closely resembling the trypsin of the mammalian pancreas. It is activated by extracts of the intestinal mucous membrane, having, by itself, little or no action, and has an optimum $\mathrm{pH}$ between 7.5 and 8.5 (Fig. 3). Polypeptidases, also, were definitely present in most samples of bile obtained by slitting the gall-bladder (compare Table III).

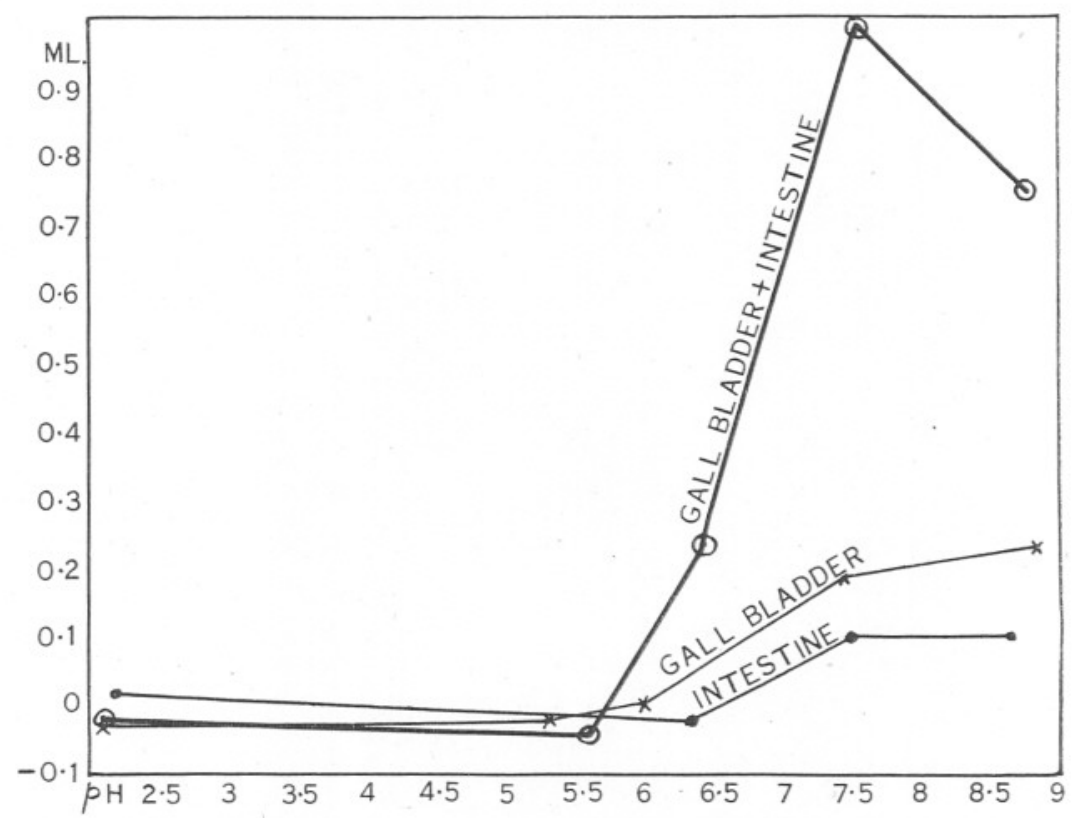

FIg. 3.-pH-Activity Curve of Proteinases in Glycerol extract of Intestinal Mucous Membrane and in Bile extract of Gall-Bladder.

Gall-bladder from $1145 \mathrm{~g}$. fish. Volume of Bile: $11 \mathrm{ml}$. Intestinal extract from $570 \mathrm{~g}$. fish. Volume of extract: $12 \mathrm{ml}$.

Substrate: casein. Ordinates: decrease in peptide linkages (formol titration) in $8 \cdot 2$ hours in terms of $\mathrm{ml} . \mathrm{N} / 50 \mathrm{NaOH}$.

- Action of intestinal extract alone.

$\times$ Action of gall-bladder extract alone.

๑) Action of mixture of both in equal proportions.

Mackay's (1929b) experiment was repeated and confirmed, the gallbladder in this case being dropped into Zenker's fluid for about 5 seconds ; bile obtained by slitting the wall of the gall-bladder after fixation of the pancreatic tissue surrounding it, was free from proteoclastic activity.

In the plaice, however, a more crucial method is available, since the bile duct can be cannulated and the bile obtained without damage to the wall of the gall-bladder. Such bile was uniformly devoid of proteoclastic action. If, on the other hand, the bile is allowed to extract the gallbladder for 1 to 2 days, an extremely active preparation is obtained 
(Table I). That the enzyme concerned is truly a trypsin, and not a cathepsin-which might be found in any tissue-is shown by Expt. 94/98 (Fig. 3). It can be seen (1) that the mixture of gall-bladder extract with intestinal extract is very much more active than either alone, and (2) that the greatest activity in all the extracts occurs between $\mathrm{pH} 7.5$ and $\mathrm{pH} 8.5$ (the complete inactivity of the intestinal extract in solutions more acid

\section{TABLE II.}

\section{Proteoclastic Action of Bile.}

Difference between the Formol Titration figures (ml. N/50 NaOH) of solutions containing $1 \mathrm{ml}$. diluted bile, $1 \mathrm{ml}$. buffer $\mathrm{pH} 7 \cdot 5-8,1 \mathrm{ml}$. of substrate solution, and $1 \mathrm{ml}$. of intestinal extract (fresh or boiled), and of similar solutions containing boiled bile, after 24 hours at $25^{\circ}$.

Total

Total Volume of

Fish Weight, Intestinal Dilution

Number. grams. Extract. of Bile.
Activity (ml. N/50 NaOH) due to

$$
\text { Bile in }
$$

presence of Intestinal

Bile Intestinal Extract

Substrate. alone. Extract. alone.

\begin{tabular}{cccccccc}
\multicolumn{7}{c}{ A. Uncontaminated Bile. } \\
$(51,53)^{*}$ & 535 & 6 & 5 & Horse serum & 0 & $0 \cdot 05$ & $0 \cdot 10$ \\
$57 \dagger$ & 390 & - & - &,,$\quad$, & 0 & - & - \\
$61,62,63 \dagger$ & 940 & 13 & 5 & Casein & 0 & $0 \cdot 05$ & $0 \cdot 32$ \\
$(66,67) \dagger$ & 665 & 8 & $4 \cdot 7$ &,, & 0 & 0 & $0 \cdot 35$ \\
$68 \dagger$ & 655 & 10 & $4 \cdot 5$ &,, & $-0 \cdot 05$ & $-0 \cdot 05$ & $0 \cdot 20$ \\
$(69,70) \ddagger$ & 380 & 5 & 6 &,, & - & - & $0 \cdot 15$ \\
$72 \dagger$ & 765 & $5 \cdot 5$ & $4 \cdot 5$ &,, & $-0 \cdot 10$ & 0 & $1 \cdot 20$
\end{tabular}

B. Bile obtained by Slitting Gall-Bladder.

\begin{tabular}{|c|c|c|c|c|c|c|}
\hline 42 & 750 & 11 & 4 & $\left\{\begin{array}{l}\text { Horse serum } \\
\text { Peptone }\end{array}\right.$ & $\begin{array}{l}0 \cdot 13 \\
0 \cdot 14\end{array}$ & - \\
\hline 44,46 & 430 & 14 & 5 & $\{$ Horse serum & $0 \cdot 10$ & - \\
\hline $\begin{array}{c}48,49 \\
59\end{array}$ & $\begin{array}{l}510 \\
930\end{array}$ & $\begin{array}{r}8 \\
15\end{array}$ & $\begin{array}{l}5 \\
7 \cdot 5\end{array}$ & $\begin{array}{l}\text { Horse serum } \\
\text { Casein }\end{array}$ & $\begin{array}{l}0 \cdot 06 \\
0\end{array}$ & $\begin{array}{l}0 \cdot 68 \\
0 \cdot 12\end{array}$ \\
\hline
\end{tabular}

C. Bile allowed to Extract Gall-Bladder.

$\begin{array}{cccccccc}40,41 & 770 & 6 \cdot 5 & 4 & \text { \{ Horse serum } & 0 \cdot 10 & - & - \\ \text { Peptone } & 1 \cdot 45 & - & 3 \cdot 05 \\ 50,52 & 550 & 6 & 5 & \text { Horse serum } & 0 & 0 \cdot 90 & 0 \cdot 10 \\ 54 & 265 & - & 5 & \text { Horse serum } & - & 0 \cdot 65 & - \\ 68 & 655 & 10 & 4 \cdot 5 & \text { Casein } & 0 \cdot 05 & 1 \cdot 85 & 2 \cdot 0\end{array}$

to $\mathrm{pH} 6.5$ is unusual, as there is more often a small quantity of cathepsin present-see Fig. 4). It is much more likely that the gall-bladder extract is activated by the enterokinase in the intestinal extract, than that the intestinal extract is activated by some substance in the gall-bladder.

It would appear, then, that pure bile has no proteoclastic activity, but that the layer of pancreatic tissue surrounding the gall-bladder is capable

* Gall-bladder fixed in Zenker's fluid.

$\dagger$ Bile obtained by cannula in bile-duct.

$\mp$ Bile obtained by cannula, after acid had been inserted in intestine. 
of secreting a trypsin-like enzyme. There does not appear to have been any special duct described, through which this pancreatic juice could reach the intestine, and it is tempting to suppose that secretion takes place into the gall-bladder and that the enzyme reaches the intestine in the bile. If this is the case, it should be possible to make pure bile (as obtained by cannulating the bile duct) active in digesting proteins, by treating the fish with pilocarpine. This experiment has been performed eight times, the fish being on an artificial circulation of sea-water, and under urethane as described later. The bile duct was ligatured at the beginning of the experiment, between the entry of the hepatic ducts and the intestine in four

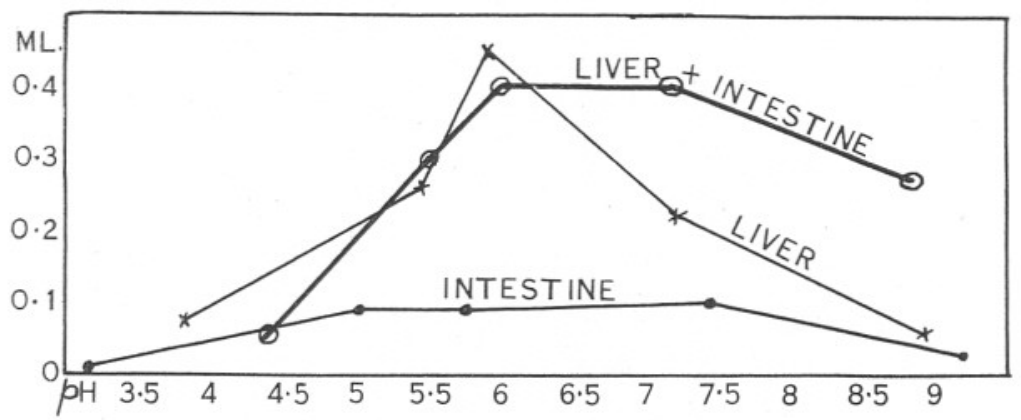

FIG. 4.- pH-Activity Curve of Proteinases from Glycerol extracts of Intestinal Mucous Membrane and of Liver.

Total weight of fish : $745 \mathrm{~g}$. Volume of intestinal extract : $12 \mathrm{ml}$. Volume of liver extract: $17 \mathrm{ml}$. Substrate : casein. Ordinates: decrease in peptide linkages (formol titration) in $6 \cdot 2$ hours in terms of $\mathrm{N} / 50 \mathrm{NaOH}$.

- Action of intestinal extract alone.

$\times$ Action of liver extract alone.

$\odot$ Action of mixture of both in equal proportions.

experiments, and at the base of the gall-bladder in four experiments ; in the former, bile secreted by the liver during the experiment, possibly containing pancreatic juice, would be included in the sample of bile collected ; in the latter, it would not. At the end of the experiment, the bile duct was cannulated close to the base of the gall-bladder, and the bile expelled by gentle pressure with the fingers. The pilocarpine (as nitrate or chloride) was added to the circulating sea-water (total volume 300 to $400 \mathrm{ml}$.), and its effectiveness was checked by counting the frequency of the heart beat.

It is difficult to expose the heart of the plaice sufficiently for direct visual observation, so an electrode was placed on the pericardium and another either under the tail or in the gill cavity, and the action potential waves were counted. Since it was not necessary to make distortionless records, the leading off electrodes were connected to a three-stage amplifier with a milliammeter in the anode circuit of the last stage ; the time for twenty kicks of the milliammeter needle was measured with a stop-watch. It was sometimes necessary 
to stop the flow of water through the gills while the heart frequency was being measured, owing to the large slow potential waves associated with the rhythmic flow of water through the gills. The exact origin of these waves has not yet been ascertained. One fish showed a marked and progressive slowing of the heart when the circulation through the gills was stopped, but this was not observed in any other fish.

One experiment was performed without the addition of pilocarpine. The heart frequency immediately after the operation was 51 beats per minute ; it rose to 57 within five minutes, fluctuated, during the course of the experiment, between 52 and 60 , and was 54.5 after five hours on the artificial circulation.

The results of the analyses of the bile obtained in these experiments are

\section{TABLE III.}

Action of Pilocarpine on Proteoclastic Activity of Bile. Conditions of digestion experiments as in Table II. Substrate : Casein.

\begin{tabular}{|c|c|c|c|c|c|c|c|c|c|}
\hline \multirow{7}{*}{$\begin{array}{c}\text { Fish } \\
\text { Number. } \\
71 \\
75 \\
78^{*} \\
81\end{array}$} & \multirow{4}{*}{$\begin{array}{c}\text { Weight } \\
\text { grams. } \\
513\end{array}$} & \multirow{4}{*}{$\begin{array}{c}\text { Total } \\
\text { Volume } \\
\text { of } \\
\text { Intestinal } \\
\text { Extract. } \\
7.5\end{array}$} & \multirow{4}{*}{$\begin{array}{c}\text { Dilu- } \\
\text { tion } \\
\text { of } \\
\text { Bile. } \\
6.5\end{array}$} & \multirow{3}{*}{$\begin{array}{c}\text { Dose } \\
\text { of } \\
\text { Pilo- } \\
\text { carpine }\end{array}$} & \multirow{2}{*}{\multicolumn{2}{|c|}{$\begin{array}{c}\text { Frequency of } \\
\text { Heart beats } \\
\text { per min. }\end{array}$}} & $(\mathrm{ml} . \mathrm{N} / 5$ & $\begin{array}{l}\text { Activity } \\
0 \mathrm{NaOH}) \mathrm{du} \\
\text { Bile in }\end{array}$ & e to \\
\hline & & & & & & & 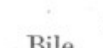 & presence of & Intestinal \\
\hline & & & & & & ninal. & $\begin{array}{l}\text { Bile } \\
\text { alone. }\end{array}$ & $\begin{array}{l}\text { Intestinal } \\
\text { Extract. }\end{array}$ & $\begin{array}{l}\text { Extract } \\
\text { alone. }\end{array}$ \\
\hline & & & & 6 & 50 & 38.5 & $0 \cdot 13$ & 0.15 & 0.20 \\
\hline & 495 & - & - & 10 & $47 \cdot 5$ & 35 & -0.02 & 0 & -0.12 \\
\hline & 340 & 5 & $6 \cdot 5$ & 13 & 47 & 24 & -0.07 & -0.05 & $0 \cdot 13$ \\
\hline & 460 & 5 & $4 \cdot 5$ & 13 & $48 \cdot 5$ & 0 & 0.05 & $0 \cdot 10$ & $0 \cdot 10$ \\
\hline $88 *$ & 580 & 7 & $2 \cdot 2$ & 13 & $\begin{array}{r}\text { Not } \\
\text { sur }\end{array}$ & $32 \cdot 5$ & 0 & $0 \cdot 10$ & $0 \cdot 60$ \\
\hline $89 *$ & 545 & 6 & $3 \cdot 8$ & 13 & $51 \cdot 5$ & 41 & $-0 \cdot 10$ & 0 & $0 \cdot 45$ \\
\hline 9 & 490 & 7 & $3 \cdot($ & 13 & $46 \cdot 5$ & 31 & -0.06 & 0.06 & $0 \cdot 25$ \\
\hline $93^{*}$ & 900 & 10 & $4 \cdot 5$ & 26 & $54 \cdot 5$ & $38 \cdot 5$ & -0.03 & $0 \cdot 10$ & $0 \cdot 4$ \\
\hline
\end{tabular}

given in Table III. While it is possible that in four of these pilocarpine experiments (two including the hepatic secretion, and two not) the bile had a detectable proteoclastic action, the effect is barely outside the limits of experimental error. It must be concluded, therefore, that no definite evidence has been obtained that a proteoclastic enzyme is secreted into the bile in response to the administration of pilocarpine.

\section{Liver.}

Glycerol extracts of the liver contain both cathepsin and trypsin, as is shown in Figure 4, which presents a striking contrast to Figure 3. In the absence of intestinal extract, the cathepsin is in preponderance (optimum $\mathrm{pH} 5.5$ to 6.0 ) ; in the presence of intestinal extract, the trypsin (optimum $\mathrm{pH}$ about 8 ) is activated, and the optimum $\mathrm{pH}$ of the mixture

* Duct ligatured below entry of hepatic ducts, i.e. hepatic bile not excluded.

$\dagger$ By direct examination after opening pericardium. 
is shifted to about 7. Stern (1931), who studied the proteases of the liver of the carp, demonstrated the presence of a cathepsin with an optimum $\mathrm{pH}$ of 4 and of a trypsin with an optimum $\mathrm{pH}$ of 10 , so that the $\mathrm{pH}$-activity curve contained two distinct peaks. He did not activate the trypsin with enterokinase, and studied the proteinases only, estimating the amount of digestion by a nephelometric method after precipitation with sulphosalicylic acid. The formol titration method, used in the present series, would estimate polypeptidases also, and the difference in the shape of the $\mathrm{pH}$-activity curve may be connected with this difference in technique.

\section{The Digestion of Fats.}

Methods. The method used was essentially that described by Anrep, Lush and Palmer (1925). The only modification was that at suitable intervals, the experimental tube, containing the active enzyme, was titrated with $\mathrm{N} / 5 \mathrm{NaOH}$ to the same $\mathrm{pH}$ as the control tube, containing the boiled enzyme. In this way the turbidity and colour of the extract were compensated, and the hydrogen-ion concentration was not allowed to drift out of the optimum range of the enzyme. The figures obtained in this way for the activities of the various extracts were also independent of the buffer value of the digests.

\section{RESULTS.}

\section{A. Stomach.}

Dawes (1930) states that histological examination of the walls of the stomach of the plaice after feeding shows that absorption of fats takes place from the stomach. Accordingly, the extracts of the mucous membrane of the stomach were examined for lipoclastic activity. None could be found at $\mathrm{pH} 2 \cdot 5,4 \cdot 5$ to $6 \cdot 0$, or $7 \cdot 5$ to $8 \cdot 5$, at any season of the year.

\section{B. The Intestine.}

Extracts of the mucous membrane of the intestine showed a powerful lipoclastic activity, which was increased by the addition of bile. The optimum hydrogen-ion concentration lay between $\mathrm{pH} 7.5$ and $\mathrm{pH} 8.0$, although the activity does not vary very considerably over the range $\mathrm{pH} 6$ to $\mathrm{pH} 9$ (Fig. 5). The portion distal to the cæca showed a greater activity than the portion containing the cæca, so that there is no reason to suppose that the enzyme is particularly associated with these organs (Table IV).

\section{Bile.}

Bile removed from the gall-bladder without any special precautions against contamination with the pancreatic tissue showed a negligible lipoclastic activity. The plaice appears to differ in this respect from 
Fundulus (Babkin and Bowie, 1928). Bile which has been allowed to extract the gall-bladder, however, showed on one occasion an activity comparable in magnitude to that of the intestine ; on another occasion, there was no activity.

\section{TABLE IV.}

Lipoclastic Action of Intestinal Extracts.

$\mathrm{ml}$. $\mathrm{N} / 5$ acid produced by $1 \mathrm{ml}$. extract in 7 hours at $\mathrm{pH} 7 \cdot 5$ to 8 .

Three fish of total weight $715 \mathrm{~g}$. Proximal portion of intestine taken as $23 \%, 10 \cdot 5 \%$ and $10 \cdot 7 \%$ of whole ; last two had distal cæca. Both extracts made up to about $6 \mathrm{ml}$.

$\begin{array}{cccc}\text { Portion of Intestine. } & \text { Without Bile. } & \text { With Bile. } & \text { Bile only. } \\ \text { Proximal } & 0 \cdot 10 & 0 \cdot 13 & 0 \cdot 02 \\ \text { Distal } & 0 \cdot 28 & 0 \cdot 33 & 0 \cdot 01\end{array}$

\section{Liver.}

Glycerol extracts of the liver possessed an extremely powerful lipoclastic action (Fig. 5).

\section{The Digestion of Carbohydrates.}

Methods. Preliminary studies were made with the achromic point method, in which a drop of a solution of iodine in potassium iodide is

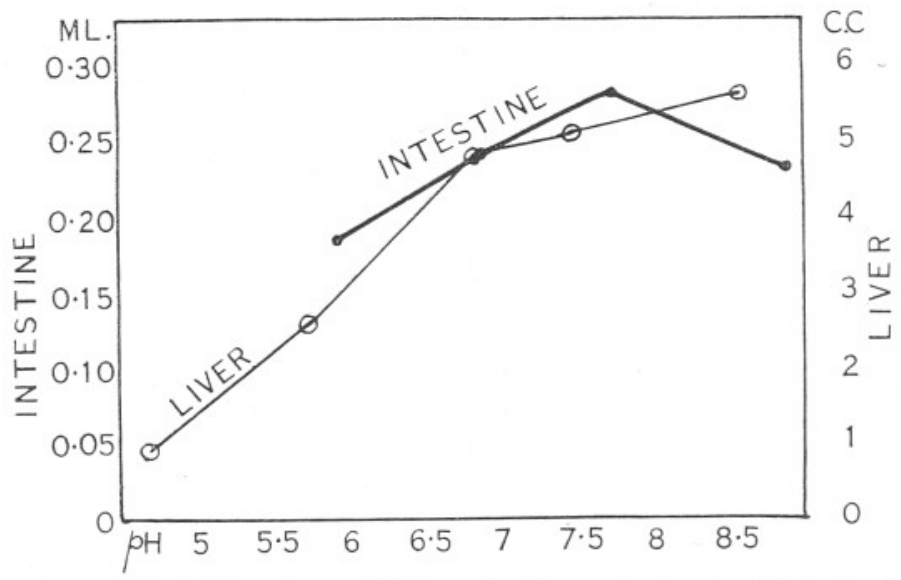

Fig. 5.- pH-Activity Curve of Lipases in Glycerol extracts of Intestinal Mucous Membrane and of Liver.

Substrate: triacetin. Ordinates : acid produced per hour by extract of whole organ from $1 \mathrm{~kg}$. of fish in terms of $\mathrm{N} / 5 \mathrm{NaOH}$.

- Expt. 61/63. Intestinal mucous membrane. Duration of digestion: 7 hours.

๑) Expt. 94/95. Liver. Duration of digestion 2.5 hours.

The activity of the liver preparation is about 20 times as great as that of the intestinal preparation.

added to the tubes containing starch and the enzyme extract, and starch and the boiled extract, respectively; the absence of blue colour, or the 
presence of a purple or red colour, indicates that some digestion has taken place. More precise studies were then undertaken in which the sugar concentration of the digests was estimated by Benedict's method. Since, in many cases, the volume of solution available was insufficient to reduce completely even $1 \mathrm{ml}$. of Benedict's solution, the titration was carried to completion with a standard solution of maltose, and the sugar concentration (in terms of maltose) of the digest estimated by difference.

\section{RESULTS.}

\section{A. Stomach.}

No amyloclastic activity could be detected in the stomach extracts at $\mathrm{pH} 2,4$ or 6 .

\section{B. Intestine.}

A definite, but not very powerful activity was found in the extracts of the intestinal mucous membrane, with an optimum hydrogen-ion

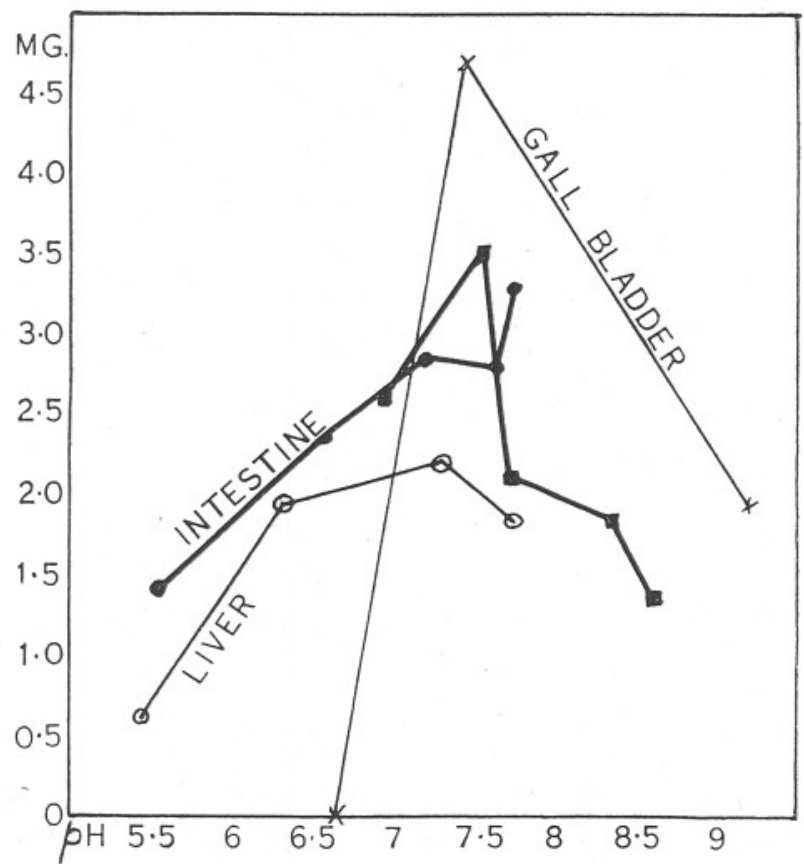

FIg. 6.- $\mathrm{pH}$-Activity Curve of Amylases in Glycerol extracts of Intestinal Mucous Membrane, of Liver, and in Bile extract of Gall-Bladder.

Substrate: starch. Ordinales: mg. sugar (as maltose) produced per hour by extract of whole organ from $1 \mathrm{~kg}$. of fish. Duration of digestion : 23 hours.

- Expt. 41. Intestinal mucous membrane.

- Expt. 43. Intestinal mucous membrane.

$\odot$ Expt. 99/100. Liver.

$\times \quad$ Expt. 99/100. Gall-bladder. 
concentration at $\mathrm{pH} 7.5$ to 8.0 (Fig. 6). The extracts of the portion distal to the cæca had a definitely greater action than those of the portion containing the cæca, so that it would appear that the enzyme is secreted by the cells of the intestine, and not primarily by those of the pancreatic tissue.

It was observed, somewhat unexpectedly, that the addition of small amounts of $\mathrm{NaCl}(0 \cdot 05 \%$ to $0 \cdot 1 \%)$ to the digests resulted in a marked increase in activity as shown in Table V. This has been observed by Cole

\section{TABLE V.}

\section{Amyloclastic Action of Intestinal Extracts.}

Solutions contained initially $0 \cdot 3 \%$ starch, buffered at $\mathrm{pH} 7 \cdot 5$ and $1 \mathrm{ml}$. of extract. Sugar concentrations are expressed as $\mathrm{mg}$. maltose per $\mathrm{ml}$.

\begin{tabular}{|c|c|c|c|c|c|c|}
\hline \multirow{5}{*}{$\begin{array}{l}\text { Expt. No. } \\
38\end{array}$} & \multirow{5}{*}{$\begin{array}{c}\text { Wt. of } \\
\text { Fish } \\
\text { g. } \\
520\end{array}$} & & & \multicolumn{3}{|c|}{$\begin{array}{c}\text { Sugar Concentration after } \\
24 \text { hours at } 25^{\circ} .\end{array}$} \\
\hline & & & Total & & & Active \\
\hline & & Por & Volume & Bo & Ac & $\begin{array}{l}\text { Extract } \\
+0.07 \%\end{array}$ \\
\hline & & Intestine. & Extract. & Extract. & Extract. & NaCl. \\
\hline & & Prox. $45 \mathrm{mn}$ & $3 \mathrm{ml}$. & 0 & $0 \cdot 7$ & $1 \cdot 35$ \\
\hline & & Dist. $275 \mathrm{~mm}$. & $3 \mathrm{ml}$. & 0 & 1 . & $1 \cdot 0$ \\
\hline 39 & 410 & Prox. $12 \mathrm{mr}$ & 51 & $0 \cdot 35$ & $0 \cdot 65$ & $1 \cdot 0$ \\
\hline & & Dist. $170 \mathrm{~mm}$. & $6.5 \mathrm{ml}$. & $0 \cdot 45$ & $0 \cdot 8$ & $1 \cdot 45$ \\
\hline
\end{tabular}

(1903) in the case of human ptyalin, but it was not expected that the concentration of chlorides in extracts from marine fishes would be low enough for the effect to be observed. Actually, one extract from the proximal portion was found to contain only $0.0065 \% \mathrm{NaCl}$, two from the distal portions to contain $0 \cdot 03 \%$ and $0.05 \%$ respectively, and one from the whole intestine $0.023 \%$.

$$
\text { C. Bile. }
$$

No amyloclastic action could be detected in the bile unless it had been allowed to extract the gall-bladder. The activity was then comparable to that of the intestinal extracts, and had the same optimum $\mathrm{pH}$ (Fig. 6).

\section{Liver.}

Glycerol extracts of the liver had an amyloclastic action of the same order of intensity as those of the intestinal mucous membrane; the optimum $\mathrm{pH}$ appears also to be the same (Fig. 6).

\section{The Hydrogen Ion Concentration of the Contents of the Alimentary Canal.}

If the enzymes extracted from the mucosa of the alimentary canal are to be of any service to the animal, the medium in which they work must 
be of the correct hydrogen ion concentration. Accordingly, in a number of fishes, the abdomen was opened, a ligature tied round the rectum, another round the pyloric sphincter and an artery clamp placed on the lower end of the œsophagus. The whole alimentary canal was then dissected out, the stomach and intestine slit open, and the hydrogen-ion concentration of the contents measured with the quinhydrone electrode. Bile was obtained by slitting the gall-bladder in some experiments, and by cannulation of the bile duct in others.

In the majority of fishes taken from the aquarium tanks, the stomach was found empty. In these cases, two drops of distilled water were placed on the mucous membrane of the opened stomach, and, a moment or two later, withdrawn into the electrode vessel, which held $0.05 \mathrm{ml}$. The intestine always contained a clear watery fluid with a certain amount of fæcal masses, unless, of course, it contained food remnants.

The results are presented in Table VI.

\section{TABLE VI.}

Acidity of Contents of Alimentary Canal and of Bile.

\begin{tabular}{|c|c|c|c|c|c|}
\hline Fish No. & $\begin{array}{l}\text { Stomach. } \\
\text { Contents. }\end{array}$ & $\mathrm{pH}$ & $\begin{array}{l}\text { Intestine. } \\
\text { Contents. }\end{array}$ & $\mathrm{pH}$ & $\begin{array}{l}\text { Bile. } \\
\mathrm{pH}\end{array}$ \\
\hline 7 & Empty & $2 \cdot 7$ & Scraps of food & $7 \cdot 7$ & - \\
\hline 8 & Empty & - & Traces of food & $8 \cdot 2$ & - \\
\hline 9 & Empty & $6 \cdot 7$ & Traces of food & $8 \cdot 5$ & - \\
\hline 10 & Empty & - & Traces of food & $8 \cdot 0$ & $7 \cdot 3$ \\
\hline 12 & Empty & - & Traces of food & $8 \cdot 3$ & $7 \cdot 4$ \\
\hline 16 & Polychætes & $5 \cdot 55$ & Fæcal matter & $8 \cdot 65$ & - \\
\hline 18 & Not identified & - & Scraps of food & $7 \cdot 43$ & - \\
\hline 19 & Crustacea-not identified & $\bar{z}$ & Traces of food & $7 \cdot 55$ & - \\
\hline 21 & Empty & $7 \cdot 33$ & Traces of food & $8 \cdot 33$ & - \\
\hline 22 & Empty & $7 \cdot 05$ & Traces of food & $8 \cdot 10$ & - \\
\hline 23 & Empty & $6 \cdot 45$ & Empty & $8 \cdot 10$ & - \\
\hline 30 & 0.5 c.c. fluid & $2 \cdot 40$ & Traces of food & $8 \cdot 10$ & - \\
\hline 64 & Not identified & $6 \cdot 45$ & Food-not identified & $8 \cdot 35$ & - \\
\hline 65 & Not identified & $6 \cdot 30$ & Not identified & - & - \\
\hline 66 & Full of clear fluid & $6 \cdot 85$ & Clear fluid only & $8 \cdot 20$ & $\overline{5}-75+$ \\
\hline $75^{*}$ & Empty & - & Traces of fæces & - & $5 \cdot 75+$ \\
\hline $81^{*}$ & 0.5 c.c. fluid & $5 \cdot 60$ & Traces of fæces & - & $\begin{array}{l}7 \cdot 60^{\dagger} \\
8 \cdot 00 \dagger\end{array}$ \\
\hline 82 & Empty & - & Traces of fæces & - & $\begin{array}{l}7 \cdot 70^{\circ} \\
7 \cdot 80^{\circ}\end{array}$ \\
\hline 83 & Empty & - & Traces of fæces & - & $\begin{array}{l}7 \cdot 25 \\
7 \cdot 35 \dagger\end{array}$ \\
\hline 84 & Empty & - & Traces of fæces & - & $\begin{array}{l}7 \cdot 60 \\
7 \cdot 70 \dagger\end{array}$ \\
\hline $88^{*}$ & Clear fluid & $6 \cdot 7 \S$ & Clear fluid only. & - & - \\
\hline $89 *$ & Clear fluid & - & Clear fluid only & - & $8 \cdot 05$ \\
\hline 90 & 4 e.c. elear fluid & $3 \cdot 90$ & Clear fluid only & - & $7 \cdot 60$ \\
\hline 99 & $\begin{array}{l}\text { Upogebia almost undi- } \\
\text { gested. } 5 \text { drops of } \\
\text { water added }\end{array}$ & $7 \cdot 60$ & $\begin{array}{l}\text { Upogebia. Partly } \\
\text { digested. }\end{array}$ & $8 \cdot 25$ & - \\
\hline 100 & $\begin{array}{l}\text { Upogebia almost com- } \\
\text { pletely digested }\end{array}$ & $3 \cdot 15$ & $\begin{array}{l}\text { Upogebia almost com- } \\
\text { pletely digested }\end{array}$ & $8 \cdot 20$ & - \\
\hline & $\begin{array}{l}* \text { Pilocarpine experiment. } \\
\text { * After dilution four-fold a }\end{array}$ & - & $\begin{array}{l}\dagger \text { After dilution } \\
\S \text { By indicator. }\end{array}$ & $r-f$ & \\
\hline
\end{tabular}


It will be observed that in no case did the acidity of the food within the stomach reach so high a value as one would expect if the digestion were being carried out by pepsin. It must be remembered, however, that the figures given in the table represent the mean acidities of the whole food mass, and it is highly probable that on the surface, where digestion is taking place, the acidity would be very much greater.

In order to confirm the fact that the stomach is capable of secreting acid, a number of fishes were anæsthetised with urethane, and placed on an artificial circulation of sea-water, containing about $0.8 \%$ to $1.0 \%$ urethane. Aeration was carried out, and the circulation maintained, by a modification of the spray method described by von Euler and Heymans (1932). The concentration of urethane was adjusted so as to be high enough to prevent reflex activity, but not so high as to stop the respiratory movements entirely. The fishes appeared to survive well under these conditions, many experiments lasting over 5 hours. Since it was felt that it was undesirable to pass a stomach tube, owing to the risk of leakage of sea-water through the cardiac sphincter, a cannula was tied in the pyloric sphincter. All dissection, except the first skin incision, was done with an electric cautery, and not more than one or two drops of blood were lost.

The following experiments were performed :-

(1) In several fishes, 1 to $1.2 \mathrm{ml}$. of clear watery fluid of $\mathrm{pH} 5 \cdot 5$ to $5 \cdot 9$ were withdrawn as soon as the cannula was inserted.

(2) $1 \mathrm{ml}$. of sea-water ( $\mathrm{pH} 8 \cdot 3$ ) containing phenol red was placed in the stomach, and withdrawn a few minutes later a full yellow colour $(\mathrm{pH}$ less than 7).

(3) $1 \mathrm{ml} . \mathrm{M} / 10 \mathrm{Na}_{2} \mathrm{CO}_{3}$ were inserted, withdrawn after 2 hours and titrated with $\mathrm{N} / 10 \mathrm{HCl}$. It was found that 0.07 millimols of acid (equivalent to $0 \cdot 7 \mathrm{ml} . \mathrm{N} / 10 \mathrm{HCl}$ ) had been added while the solution was in the stomach.

(4) $1 \mathrm{ml}$. of $\mathrm{M} / 10$ phosphate buffer $\mathrm{pH} 8.0$ was inserted and withdrawn after 1 hour with a $\mathrm{pH}$ of less than $7 . \quad 0 \cdot 1 \mathrm{ml}$. of $\mathrm{N} / 5 \mathrm{NaOH}$ were required to bring it back to $\mathrm{pH} 8.0$; this is equivalent to the secretion of 0.02 millimols of acid.

In an attempt to obtain a sample of bile without handling the gallbladder, the common bile duct of one fish was cannulated, and $2 \mathrm{ml}$. of $\mathrm{N} / 10 \mathrm{HCl}$ inserted into the duodenum; it was hoped that sufficient cholecystokinin might be liberated to cause a contraction of the gallbladder. This anticipation was not realised, and the bile had to be expelled by pressure on the gall-bladder. (This bile contained no proteoclastic enzymes.) After half an hour, the intestine was removed and the contents titrated with $\mathrm{N} / 5 \mathrm{NaOH}$. $1.5 \mathrm{ml}$. of $\mathrm{N} / 10 \mathrm{HCl}$ had disappeared, either by 
neutralisation or absorption. It is impossible to be certain whether this indicates a true secretion of base by the walls of the intestine, or whether there had been merely a diffusion interchange with the buffers of the blood, but in any case there is no doubt that the acid secreted by the stomach can be neutralised in the intestine.

\section{The Relative Potency of the Extracts from Various Organs.}

The amount of digestion produced per hour by the whole organ from 1 kilogram of fish has been calculated for the proteases, lipases and amylases of the stomach, intestine, gall-bladder and liver. They are given in Table VII. Owing to the very great variation between different samples,

\section{TABLE VII.}

The Relative Potency of the Extracts from Various Organs.

$$
\text { Organ. } \begin{gathered}
\text { Number of } \\
\text { Experiments. Greatest. Activity. } \\
\text { Least. Average. }
\end{gathered}
$$

A. Proteases. (1) Kerridge Method. Aetivities in mg. protein digested per hour per kg. fish Stomach. (Glycerol extract) more than 12 hours digestion less than 12 hours digestion Stomach. (Acid extract) less than 12 hours digestion Intestine. more than 12 hours digestion less than 12 hours digestion

$\begin{array}{rlrr}3 & 10 \cdot 5 & 3 \cdot 4 & 7 \cdot 0 \\ 9 & 54 \cdot 5 & 5 \cdot 2 & 25 \cdot 8 \\ 3 & 31 & 11 \cdot 5 & 21 \cdot 5 \\ 11 & 25 & 0 & 7 \cdot 3 \\ 2 & 19 & 14 & 16 \cdot 5\end{array}$

(2) Formol Titration Method. Activities expressed as decrease in peptide linkages (ml. N/50 NaOH) per hour per kg. fish.

Intestine

$\begin{array}{lllll}\text { more than } 12 \text { hours digestion } & 19 & 0 \cdot 35 & 0 & 0 \cdot 16\end{array}$

$\begin{array}{lrlll}\text { less than } 12 \text { hours digestion } & 4 & 2.5 & 0 \cdot 46 & 1 \cdot 25\end{array}$

Gall-Bladder

$\begin{array}{lllll}\text { more than } 12 \text { hours digestion } & 3 & 0 \cdot 53 & 0 \cdot 21 & 0 \cdot 40\end{array}$

$\begin{array}{lllll}\text { less than } 12 \text { hours digestion } & 3 & 10 \cdot 0 & 3 \cdot 2 & 5 \cdot 9\end{array}$

Liver

less than 12 hours digestion

5

$5 \cdot 2$

$2 \cdot 2$

$3 \cdot 4$

B. Lipases. Activities expressed as amount of acid produced (as $\mathrm{ml}$. $\mathrm{N} / 5 \mathrm{NaOH}$ ) Intestine

Gall-Bladder

Liver per hour per kg. fish.

$\begin{array}{llll}7 & 0 \cdot 92 & 0 \cdot 12 & 0 \cdot 35 \\ 2 & 0 \cdot 20 & 0 & 0 \cdot 10 \\ 2 & 5 \cdot 3 & 2 \cdot 3 & 3 \cdot 8\end{array}$

C. Amylases. Activities expressed as mg. sugar (as maltose) produced per hour per kg. fish.

$\begin{array}{lllll}\text { Intestine } & 6 & 9 \cdot 0 & 2 \cdot 8 & 5 \cdot 0 \\ \text { Gall-Bladder } & 2 & 5 \cdot 1 & 4 \cdot 7 & 4 \cdot 9 \\ \text { Liver } & 1 & - & - & 2 \cdot 2\end{array}$

it has been felt advisable to include the highest and lowest values, as well as the average. In the case of the proteases, it is clear that the activity falls off very markedly in the first few hours, so that the activity figures 
calculated from experiments of long duration are always lower than those calculated from experiments of short duration. In the table, a "long" experiment has been arbitrarily defined as one continuing for 12 hours or longer, and a "short" experiment as one continuing for less than 12 hours.

It may be concluded from these figures $(a)$ that the proteoclastic activities of the gall-bladder and liver are approximately the same, and are greater than those of the intestine and stomach; $(b)$ that the lipoclastic activity of the liver is very much greater than that of either the gall-bladder or intestine; and $(c)$ that the amyloclastic activities of the intestine, gall-bladder and liver are all approximately the same. The stomach has no lipoclastic or amyloclastic activity.

\section{SUMMARY.}

1. It has been shown that the stomach of the plaice can digest proteins by an extra-cellular enzyme - apparently pepsin. Fats and carbohydrates appear to be unattacked in the stomach.

2. In the intestine, proteins are further attacked and the mucous membrane contains a trypsin and an erepsin.

3. The liver and the wall of the gall-bladder are more potent sources of trypsin than is the intestine; the former contains, also, a cathepsin, and the latter an erepsin. It is not certain whether any of these enzymes can be secreted into the intestine ; administration of pilocarpine failed to make the bile definitely active in digesting proteins, but it is possible that there may be some other route by which the secretion may reach the intestine.

4. Fats and carbohydrates are digested in the intestine, since the mucous membrane of the intestine - and also the wall of the gall-bladder and the liver-contain lipase and amylase. The liver is a far more potent source of lipase than is either the gall-bladder or the intestine, but this lipase may be partly intra-cellular in action.

5. The hydrogen-ion concentration of the contents of the stomach and intestine has been shown to be consistent with the extra-cellular action of the enzymes found in the respective mucous membranes. The mucous membrane of the stomach is capable of secreting acid, and that of the intestine is capable of bringing about its neutralisation.

\section{REFERENCES.}

Anrep, G. V., Lush, J. L., and Palmer, M. G. 1925. Observations on pancreatic secretion. J. Physiol., 59, 434.

Babkin, B. P., and BowIE, D. J. 1928. The digestive system and its function in Fundulus heteroclitus. Biol. Bull., 54, 254. 
Cole, S. W. 1903. Contributions to our knowledge of the action of enzymes. Part I. The influence of electrolytes on the action of amylolytic ferments. J. Physiol., 30, 202.

Cole, F. J., and Johnstone, J. 1901. L.M.B.C. Memoirs VIII. Pleuronectes. London.

Dawes, Ben. 1930. The absorption of fats and lipoids in the Plaice (P. platessa L.). J. Mar. Biol. Assn., 17, 75.

Euler, U. S. v., and Heymans, C. 1932. An oxygenator for perfusion experiments. J. Physiol., '74, $2 P$.

Kerridge, P. M. T. 1931. A new clinical method for the estimation of protein in urine. Lancet, 221, 21.

Mackay, M. E. 1929a. The digestive system of the eel-pout (Zoarces anguillaris). Biol. Bull., 56, 8.

— 1929b. Note on the bile in different fishes. Ibid., 56, 24.

Northrop, J. H. 1932. Pepsin activity units and methods for determining peptic activity. J. Gen. Physiol., 16, 41.

Stern, K. G. 1931. Über die autolytische Wirksamkeit der tierischen Gewebsproteinasen und ihre Beeinflussung durch Schwermetalle. Biochem. Z., 234, 116.

Vonk, H. J. 1927. Die Verdauung bei den Fischen. Z. vergl. Physiol., 5, 445 .

Willsttäter, R., and Bamann, E. 1928. Über die Proteasen der Magenschleimhaut. Erste Abhandlung über die enzyme de Leukocyten. Z. physiol. Chem., 180, 127. 
